\title{
Commentary \\ Will Disabled Workers Be Winners or Losers in the Post-COVID-19 Labour Market?
}

\author{
Paula Holland
}

Citation: Holland, P. Will Disabled Workers Be Winners or Losers in the Post-COVID-19 Labour Market?

Disabilities 2021, 1, 161-173.

https://doi.org/10.3390/

disabilities1030013

Academic Editor: Reinie Cordier

Received: 27 May 2021

Accepted: 1 July 2021

Published: 9 July 2021

Publisher's Note: MDPI stays neutral with regard to jurisdictional claims in published maps and institutional affiliations.

Copyright: (C) 2021 by the author. Licensee MDPI, Basel, Switzerland. This article is an open access article distributed under the terms and conditions of the Creative Commons Attribution (CC BY) license (https:/ / creativecommons.org/licenses/by/ $4.0 /)$.
Division of Health Research, Lancaster University, Lancaster LA1 4YW, UK; p.j.holland@lancaster.ac.uk

\begin{abstract}
Workplace inflexibility contributes to the higher rates of job loss and unemployment experienced by disabled people. Prior to the COVID-19 pandemic, many countries already had significant disability employment gaps. Based on evidence from previous recessions, the global recession resulting from the pandemic is likely to have a severer and longer-lasting impact on the employment of disabled workers compared with non-disabled workers. In the UK, there is already evidence that the disability employment gap has widened since the pandemic. On the other hand, the pandemic initiated increased access to home-working, a change in working arrangements that may prove beneficial to disabled workers employed in desk-based roles. Home-working can increase the accessibility of employment and support work retention for disabled workers, yet pre-pandemic many employers had withheld it. Studies of employees' and employers' experiences of homeworking during the pandemic have indicated a desire to retain access to home-working in the future. A permanent cultural shift to increased access to home-working would help address the disability employment gap for desk-based workers. However, disabled workers are over-represented in jobs not conducive to home-working, and in sectors that have been hardest hit by business closures during the pandemic, so the position of many disabled workers is likely to remain precarious.
\end{abstract}

Keywords: employment; disability employment gap; employers; home-working; reasonable adjustments; COVID-19; inequities; economic recession

\section{Introduction}

COVID-19 was first identified in China in December 2019, and was announced as a worldwide pandemic by the World Health Organization in March 2020. By May 2021, over 160 million cases of COVID-19 had been confirmed globally, including more than 3 million deaths [1]. Marked social and ethnic inequities in COVID-19 mortality rates have shone a light on broader pre-existing inequities in health and social circumstances. In the UK, COVID-19 deaths have occurred disproportionately among those living in more deprived areas, among black and minority ethnic groups, older people, and people with comorbidities or disabilities [2]. Indeed, over half (59.5\%) of UK deaths involving COVID-19 up to November 2020 were among disabled people, although this is likely to be an under-estimation as it relies on disability status as recorded in the 2011 Census [3]. Women identifying as being severely disabled had a rate of death involving COVID-19 that was 4.1 times the rate in non-disabled females, while the rate for disabled men was 3.2 times that of non-disabled men.

Inequities in the employment and economic consequences of COVID-19 are also apparent. As well as experiencing high COVID-19 mortality rates, disabled people and people with long-term health conditions (hereafter referred to as 'disabled people' for brevity) are likely to experience more severe disadvantage in the labour market than other groups as a result of the pandemic. Disabled people already had significantly lower employment rates than the rest of the population before the pandemic, both in the UK and in other countries, but the disability employment gap in the UK has widened since the start of the pandemic and is likely to increase. Globally, the pandemic caused an economic recession and a major 
growth in unemployment; based on evidence from previous recessions, disabled workers will be hit the hardest, widening employment inequity between them and the rest of the population [4]. On the other hand, the unprecedented and sudden shift to nearly universal home-working for many workers in desk-based occupations during the pandemic offers the potential for a more inclusive and sustainable way of working. This article reflects on the employment prospects of disabled workers in the context of the COVID-19 pandemic. Although it largely focuses on the UK context, given the ubiquity of the issues raised it will have resonance in other settings.

\section{The Disability Employment Gap: Pre-COVID-19}

In the UK, $19 \%$ of the working age population report having a disability (a physical or mental impairment that has substantial and long-term negative effects on the ability to do normal daily activities), although this rate varies from $24 \%$ in the Northeast of England to $15 \%$ in London [5]. Access to employment is not equally distributed, and people who become disabled during their working life are nearly four times more likely to become jobless than non-disabled people [6]. Disabled workers in the UK had significantly lower employment rates than other workers even before the pandemic devastated the economy: in $2019,53.6 \%$ of disabled people were employed compared with $81.7 \%$ of non-disabled people, producing a disability employment gap of 28.1 percentage points [7]. This overall figure, however, masks the more severe employment disadvantage experienced by specific groups of disabled people. For example, the disability employment gap:

- $\quad$ is highest for people with mental illnesses and severe/specific learning difficulties (53 and 64 percentage points respectively);

- $\quad$ varies by gender (a gap of 32 percentage points for men; 25 for women);

- $\quad$ increases with age (a gap of 35 percentage points for workers aged 50-64);

- $\quad$ increases with decreasing levels of educational attainment, with the largest gap among people without educational qualifications (41 percentage points);

- $\quad$ varies by UK region, and is highest in Northern Ireland (42 percentage points) and lowest in the Southeast of England (23\%) [8].

Employment inequities are ubiquitous, but the UK's disability employment gap is the fourth highest among the European Union nations and significantly higher than that observed in Finland (19\%), Sweden (18\%) and France (18\%) [9]. However, these marked national and international inequities in employment rates for disabled people indicate that they are tractable and can be addressed through policy interventions focusing on the underlying structural and institutional factors driving them, if there is sufficient willpower from the government and employers.

Disabled people in employment also face inequities. They are more likely to work part-time [7], and on average earn $12 \%$ less than other employees, partly due to their under-representation in higher-skilled and higher-paying occupations [5]. Even within occupational groups, however, they earn less than their non-disabled counterparts, and this pay gap is widest among professionals, managers, directors or senior officials [5]. The employment and financial disadvantage experienced by disabled people increases their (and their dependents') risk of poverty and social exclusion, which in turn poses health risks. A large body of evidence has documented the negative impact of unemployment on physical and mental health [10-12]. Tackling employment disadvantage-and identifying ways to prevent additional employment disadvantage associated with the COVID-19 pandemic and consequent economic recession-is crucial for addressing health and social inequality.

\section{Impact of the COVID-19 Recession on the UK Disability Employment Gap}

The pandemic led to reduced productivity worldwide and a global recession. In the UK, monthly GDP fell by a record $20.4 \%$ in April 2020 following the start of lockdown, and by September 2020 it had not returned to pre-pandemic levels [13]. Redundancies increased through business closures, decreased demand for goods and services, and reductions in output due to the introduction of social distancing measures and furlough [14]. The UK 
employment rate in the general population had been increasing following the 2007-2009 recession, but between December 2019 and December 2020 it fell by 1.5 percentage points [15] (Figure 1).

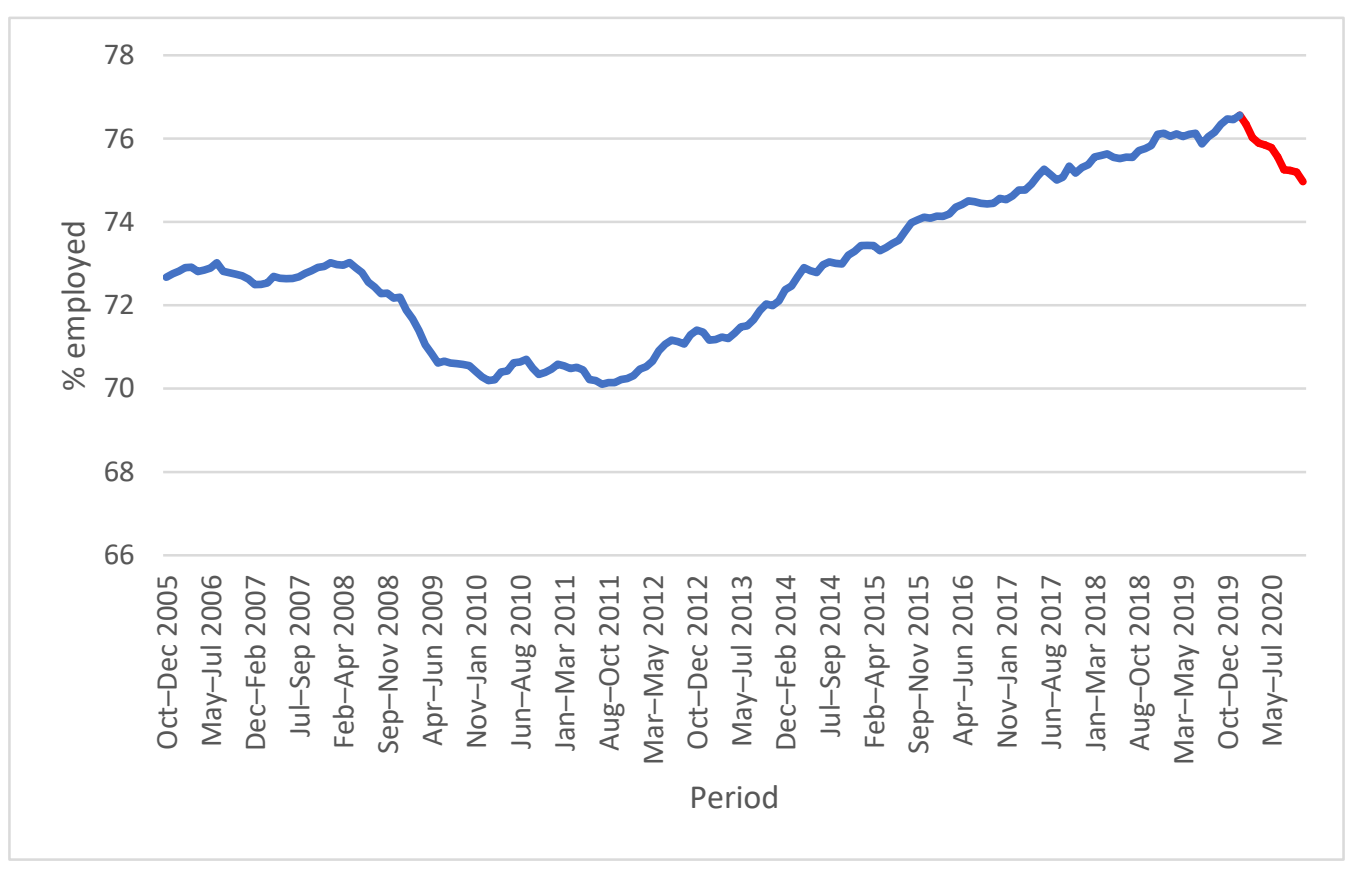

Figure 1. Employment rate, adults aged 16-64, UK: 2005-2020. The COVID-19 pandemic is indicated in red. Source: Data from the UK Labour Force Survey (Office for National Statistics 2021).

Unemployment, however, fell to a greater degree for disabled workers. As well as accounting for $60 \%$ of COVID-19 deaths in the UK, disabled people have borne the brunt of the economic consequences of the pandemic. The employment rate of disabled men had been increasing steadily, from $45 \%$ in 2013 to $55 \%$ by the end of 2019 , narrowing the male disability employment gap [15] (Figure 2), but the pandemic has started to reverse this trend. Disabled men's employment fell by 3.8 percentage points between December 2019 and December 2020, more than double the rate for non-disabled men, widening the male disability employment gap. Although the impact on disabled women's employment was smaller than that for disabled men, the decline in their employment was double that of non-disabled women (Figure 3). During the pandemic, a widening of the disability employment gap has also been observed in the USA [16].

This growing employment inequity is concerning, because recessions have greater consequences for the employment of disabled people than other workers: increased competition for jobs during recessions means employers are more likely to recruit healthy, better qualified and more experienced individuals. During the 1991-1993 UK recession, employment rates fell among non-disabled men but quickly recovered [4] (Figure 4). In contrast, not only did the employment rates of disabled men fall to a greater extent, but they continued to fall in the years following the recession, leading to increasing employment inequity. Disabled workers with a low level of education fared the worse. In contrast, Norway, Denmark and Sweden were better able to protect the employment of these groups during their 1980s-2000s recessions, due to their higher level of spending on active labour market policies compared to the UK, and an emphasis on interventions to improve the employment environment for disabled workers, alongside higher investments in medical rehabilitation and occupational health services for disabled or chronically ill people [17]. 


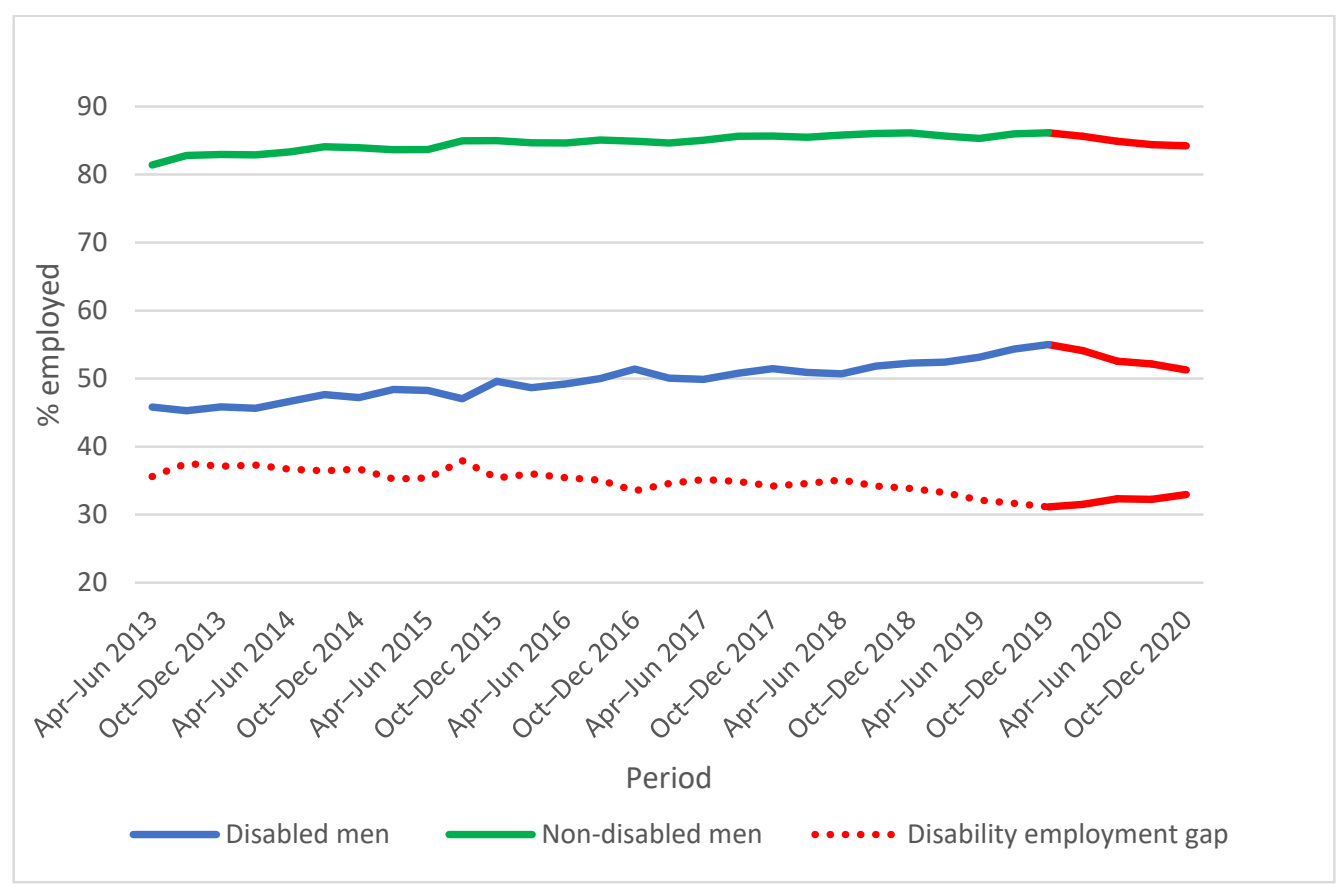

Figure 2. Employment rate, disabled men aged 16-64, UK: 2013-2020. The COVID-19 pandemic is indicated in solid red. Source: Data from the UK Labour Force Survey (Office for National Statistics 2021).

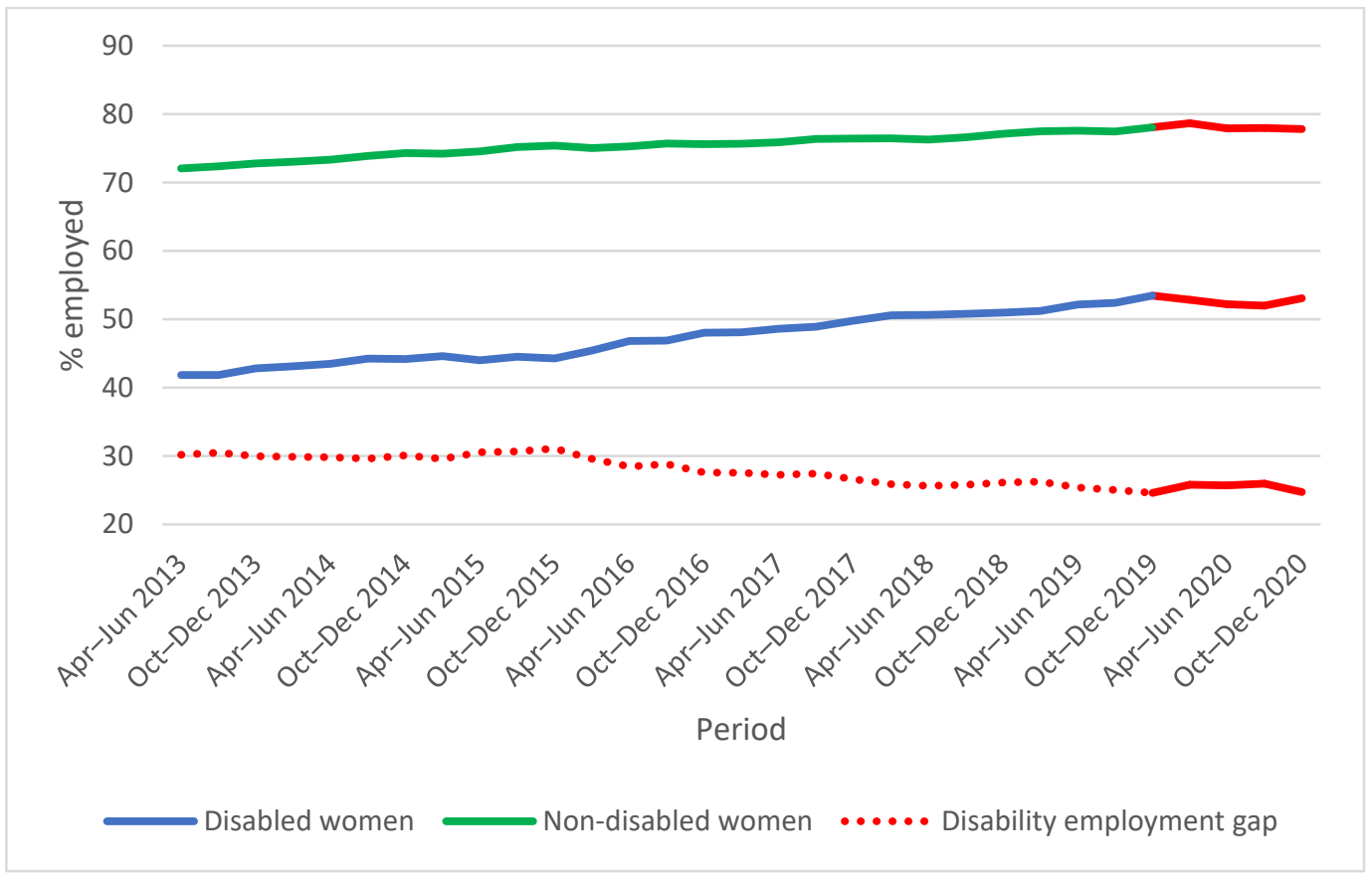

Figure 3. Employment rate, disabled women aged 16-64, UK: 2013-2020. The COVID-19 pandemic is indicated in solid red. Source: Data from the UK Labour Force Survey (Office for National Statistics 2021). 


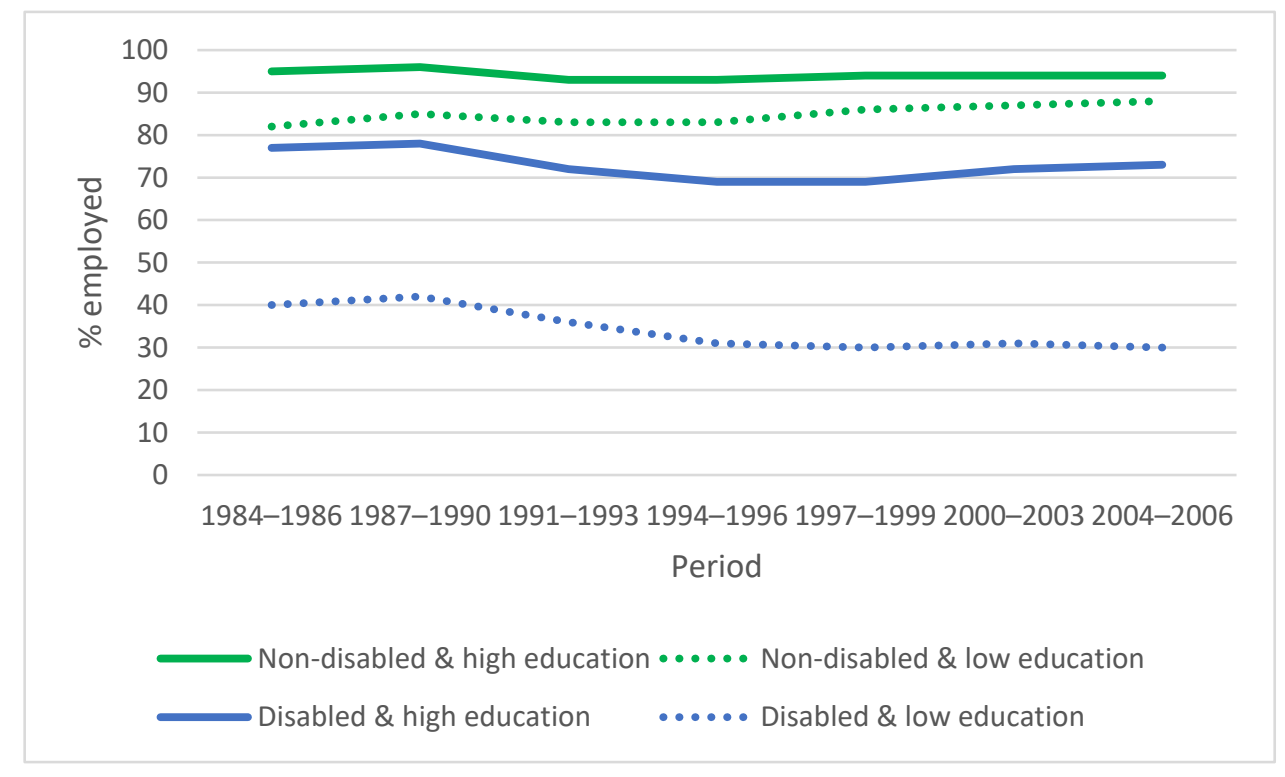

Figure 4. Impact of the 1991-1993 recession on employment rates: disabled and non-disabled men, UK: 1984-2006. Source: Data from the UK Labour Force Survey (Holland et al., 2011 [17]).

Based on this evidence, the current downturn is likely to have a more severe and longer-lasting impact on the employment rates of disabled workers than other workers. Disabled workers are over-represented in low-paid, low-skilled jobs which were more vulnerable to job losses during the pandemic lockdowns when non-essential services were suspended [18]. For example, disabled people are more likely than non-disabled people to be employed in caring, leisure and other service occupations (12.3\% vs. $8.7 \%$ respectively), or sales and customer service occupations (9.1\% vs. 6.8\%) [19].

That the recession is likely to hit disabled people harder is concerning because unemployment damages health, particularly for people unemployed due to health reasons [20]. Moreover, financial insecurity associated with economic recessions can lead to worsening health outcomes and widen social inequities in health. A Canadian study found that, during the pandemic, disabled and chronically ill workers reported higher rates of job insecurity than workers in the general population, with many reporting financial distress due to unemployment or reduced working hours [21]. In the UK, income inequality had already increased following the 2012 recession and subsequent period of austerity, and the COVID-19 pandemic has widened it further [22]. Following the MERS, Ebola and Zika epidemics, many countries observed increased income inequality alongside higher unemployment for people with lower levels of education [23]. The financial and mental distress associated with the COVID-19 pandemic job losses will be felt for many years to come.

The pandemic is also likely to adversely affect job security for disabled people, due to their experiencing more severe social and psychological consequences of COVID-19. Disabled people who self-isolated at home during the first national lockdown of the pandemic expressed anxieties concerning the impact of social distancing measures on their mobility and the accessibility of public buildings, their inability to wear a face mask if their health condition/impairment prevented it, and whether easing of lockdown measures would increase their risk of exposure to the virus [24]. The long-term consequences of the pandemic for the mental health of vulnerable groups who self-isolated for extended periods are likely to be considerable but are not yet clear [25]. Disabled people and people with long-term health conditions who self-isolated are likely to also be concerned about being at greater risk of redundancy and that prospective employers may be deterred from employing them in case they need to shield in further waves of the pandemic. 
Increased competition for jobs during recessions can deter disabled jobseekers from disclosing their impairment or health condition to potential employers (if it is invisible), denying them the ability to request workplace adjustments that would help them in their role [26]. The UK Equality Act 2010 [27] requires employers to provide reasonable adjustments to support work retention of disabled employees, yet disabled workers frequently cite organisational inflexibility, discriminatory attitudes in the workplace, and employers' unwillingness to provide flexible working arrangements and other workplace adjustments as major barriers to their remaining in, or moving into, employment [28]. Pinder (1995) describes how the presence of disabled employees in an organisation requires employers to 'think specially' rather than adopting a 'business as usual' approach, which can deter them from implementing adjustments [29]. Indeed, studies have shown employers are less willing to implement adjustments, such as flexible working arrangements that require sustained effort from them or that disrupt the daily operating of organisations, and may actively withhold or withdraw them to minimise their potential impact on the workplace [29-32]. Consequently, non-inclusive workplaces and organisational policies and practices result in higher rates of job loss, unemployment, self-employment and early retirement among disabled workers, contributing to disability employment inequity.

\section{Increased Access to Home-Working: A Cultural Shift to Level the Playing Field?}

As outlined above, the economic downturn associated with the pandemic has started widening the disability employment gap in the UK and is likely to have a greater and longer-lasting impact on the employment prospects of disabled people than other workers. Simultaneously, however, the pandemic also initiated a cultural shift in working arrangements that, if sustained, may prove beneficial to workers who have been excluded from full participation in the labour market.

Prior to the COVID-19 pandemic, many employers had been reluctant to allow employees to work from home due to lack of trust, a desire for workplace visibility and reports of unavailability of appropriate technology [33,34]. In 2019, only $5.2 \%$ of people in employment in the UK reported working mainly from home, and $12.3 \%$ worked from home at some point during the week [35]. At the start of the pandemic in March 2020, governments around the world imposed national lockdowns to reduce transmission of the virus and advised people to work from home where possible. Many organisations were forced to operate remotely for the first time, imposing compulsory home-working for their office-based workers. Almost overnight, employers had to put into place infrastructure, policies and procedures that allowed desk-based workers to home-work, many of whom are still doing so at the time of writing, 14 months later.

Data from the UK 'Understanding Society: COVID-19 Study' [36] reveal that homeworking increased dramatically during the pandemic, from $5.7 \%$ of workers in January 2020 to $43.1 \%$ in April 2020 and, even though it had fallen by June 2020, it remained high at $36.5 \%$. A higher rate of home-working was reported in a UK survey of working parents, $86 \%$ of whom reported working from home during lockdown, compared with one-third before the pandemic [37]. Once regarded as a 'perk' for managers, home-working became mandatory for the majority of office workers. Conferencing technology facilitated online meetings, while conferences and other external events usually held face-to-face were livestreamed as webinars, preventing the need to travel and making it easier for delegates to fit them into their working day.

The sudden shift to home-working has not been without its problems, however. Employees working from home during lockdown reported missing physical interaction with colleagues, and expressed concerns about blurred boundaries between work and home and lacking necessary equipment and space at home to carry out their work [37]. Working parents (particularly mothers) expressed the additional strain of having to combine working from home with caring for children, home-schooling, and increased domestic labour [37].

On the other hand, workers reported that the benefits of working from home during lockdown included flexible scheduling, the lack of a commute, extra time to spend 
with family and improved productivity and well-being $[37,38]$. These perceived benefits led a large proportion of workers to express the desire to work from home more in the future [36,37]. Indeed, $88.2 \%$ of workers in the 'Understanding Society: COVID-19 Study' indicated they wished to continue to home-work after the pandemic [36].

Working exclusively or partly from home is a reasonable adjustment that can increase the accessibility of employment for disabled workers and support their work retention, yet few studies have explored disabled workers' experiences of home-working. Those conducted prior to the pandemic revealed home-working helps disabled workers maintain workflow by allowing them greater control over their work schedule and enabling tasks to be arranged around fluctuating energy levels, pain, or medical appointments [30,39-42]. Home-working also circumvents the daily commute and difficulties associated with reduced mobility and negotiating public transport. A recent study of remote workers in the UK, US, Canada and Australia conducted prior to the pandemic found that $83 \%$ workers with a disability or long-term condition reported they were employed because of their ability to work remotely [43].

Despite the potential benefits of home-working for disabled workers, however, it has often been withheld as a reasonable adjustment by employers [44]. A study of the impact of COVID-19 on the employment of disabled lawyers in England and Wales revealed that home-working was the most commonly refused reasonable adjustment prior to the pandemic [26]. However, most of the disabled lawyers in the sample reported that home-working during the pandemic had a positive impact on their mental and physical wellbeing, and gave them increased autonomy over how and when they worked. Importantly, participants reported that the pandemic had provided them the opportunity to demonstrate that home-working was an effective and reasonable adjustment. Other benefits of home-working that they wished to see continue post-COVID-19 were easier access to remote meetings, and avoiding the need to travel to work or to consult with clients. While some disabled lawyers reported difficulties with lack of space for home-working and negative impacts on their mental health, overall experiences of home-working during lockdown were largely positive. The authors speculate this was due to: "the unprecedented nature of the situation, whereby all employees, not just a minority with protected characteristics, worked from home. Consequently, substantial efforts were made by organisations to address possible isolation, improve virtual communications, maintain organisational identity and build virtual communities" [26]. Research on the homeworking experiences and support needs of disabled workers employed in a broader range of occupations is currently ongoing at Lancaster University.

Research conducted prior to, and during, the pandemic has shown that home-working can increase productivity [45-47]. Increased productivity and cost-savings appear to be swaying some employers to maintain increased use of home-working. In September $2020,74 \%$ of company directors surveyed in the UK reported they would be keeping increased home-working post-pandemic, and $53 \%$ stated their organisation intended to reduce their long-term use of workplaces [48]. Almost half (44\%) reported this reduced use of workplaces was because 'working from home is proving more effective'. Increased use of remote working also has economic benefits for organisations able to reduce their estate costs.

This shift in employers' perspectives, from reluctance to make home-working widely available to staff, to (in some quarters) support of it, illustrates the arbitrary nature of many workplace policies and practices. The pandemic demonstrated the ability of organisations to be agile and respond swiftly in changing workplace practice to protect public health. It remains to be seen if this shift in perspective represents a permanent cultural shift in workplace policy and practice. There is likely to be increased demand for flexible and remote working from employees who perceived it as beneficial to them. In this context, organisations that offer homeworking will be more attractive to job-seekers and will have a wider pool of talent from which to draw. Importantly, making homeworking permanently and universally available to all staff would prevent the need for disabled workers to have 
to request it as a reasonable adjustment, avoiding conflict with colleagues not allowed to home-work [41].

\section{Promoting the Health and Wellbeing of Disabled Home-Workers}

Although a cultural shift to permanently increased access to home-working would increase disabled workers' access to employment, the potential disadvantages of homeworking need to be both minimized and monitored to ensure they do not adversely affect their health and wellbeing. With many employers expressing intent to reduce office space and increase use of home-working, it is important that workers have choice and control over the practice and extent of home-working. This is particularly important for disabled workers and workers with long-term conditions, for whom having the autonomy to manage their workloads around the effects of an impairment is critical for remaining in work [28,30].

Employees who had reasonable adjustments implemented in their workplace before the pandemic will require them to be maintained whilst home-working, whether the adjustments were specialist equipment or altered tasks or working hours. For employees adopting a hybrid model of home-working and working partially in the workplace and at home, this may require the purchase of additional equipment and computer software for use in both settings. In the UK, the Department of Work and Pensions' 'Access to Work' service, which contributes to or covers the cost of workplace adjustments, was extended to include the provision of workplace equipment for use in the home [49]. This additional provision will need to be permanently maintained to support disabled workers' access to home-working following the pandemic.

Home-workers may feel less visible within their organisation due to their limited physical presence in the workplace. For disabled workers, this increases the risk of their needs or difficulties being overlooked by employers, particularly workers with invisible impairments or health conditions, who tend to receive less acceptance and support from employers and co-workers than disabled workers with more visible conditions [28,32]. Employers also need to consider ways to address social isolation among home-workers. A recent study found disabled people experienced significantly higher rates of loneliness, low social support, and social isolation than non-disabled people [50]; given that some home-workers report feeling socially isolated, it is important that employers introduce measures to improve the integration of home-workers.

It is also important that home-workers do not feel pressured to work from home when they feel ill enough to be on sick leave (sickness presenteeism). Again, choice and control are important: a study of employees with rheumatoid arthritis found that voluntarily working when feeling unwell could help distract from pain and aid recovery, but feeling pressured to work when ill was detrimental to both the individual and their organisation [30].

\section{Inequities in Homeworking Opportunities}

Although increased availability of home-working could help level the playing field for disabled workers in desk-based occupations by improving their access to employment, it will only partially address the disability employment gap. Prior to the pandemic, home-working was not available to all desk-based workers, and was more common among managers, directors and those in professional occupations and workers with higher qualifications [35]. It was also more common in certain sectors and regions of the UK: among employees in the information, communication and scientific sectors, and workers in London and the South of England.

The pandemic reinforced these patterns. The surge in home-working triggered by the first lockdown in the UK was experienced most strongly by the highest paid, the better qualified, the higher skilled and those living in London and the Southeast of England [36]. On the other hand, disabled workers are over-represented in low-paid, low-skilled jobs in which homeworking is less widely available [7]. Lower income households are less 
likely to have access to the internet than higher earners [51]. Moreover, in 2017, 56\% of UK adults who had never or rarely used the internet were disabled; the highest proportion of internet non-users was observed in young disabled people aged $16-24$ years $(60 \%)$, the same proportion as found in disabled adults aged over 75 years [52]. This is notable, given the importance of internet access for accessing post-secondary education and applying for jobs. Consequently, although a culture of increased access to homeworking post-COVID-19 would improve disabled workers' access to the labour market, they are unlikely to benefit to the same extent as non-disabled workers.

The regions of the UK outside of the wealthier Southeast of England are those with the highest rates of disability, the highest disability employment gap, and the lowest rates of home-working (before and during the pandemic). In addition, the pandemic had severer consequences for the North than the South of England in terms of COVID-19 mortality and increased unemployment [53], exacerbating existing regional inequities [54]. Regional inequities in rates of disability, general unemployment and the disability employment gap strengthen the argument for retaining increased access to homeworking. A recent report called for the UK government to promote increased access to homeworking to boost employment and local regeneration, and for regional regeneration policies to be focussed on locations with fewer home-workers [55]. To support home-working, the report further recommended that jobs should be 'flexible by default', including being geographically flexible, with employers being required to demonstrate why a specified location is required in their particular circumstances. Permanently increased access to homeworking in the current labour market, and the introduction of a greater number of new jobs designed for home-working, would unlock access to wider national and international labour markets, improving access to employment for disabled workers in desk-based roles, particularly those living in areas with high unemployment, while also boosting the employment prospects of all workers living in rural, coastal and deprived communities with less buoyant labour markets.

\section{Wider Impacts of Increased Home-Working}

Increased availability of home-working jobs will have other economic and environmental implications. During the pandemic, the shift of economic activity away from cities to local economies boosted smaller independent businesses located within suburbs where commuters live. A recent UK study modelled the potential impact on local economies if city centre businesses servicing commuters, such as cafes, restaurants, pubs and taxi services, relocate to areas with a high density of home-workers [56]. The study concluded that a greater number of neighbourhoods would benefit than lose out, because desk-based work that had been highly concentrated in urban centres would be spread across a greater number of residential neighbourhoods. On the other hand, the authors suggest this trend may increase geographical inequities within local areas, because wealthier neighbourhoods that were already desirable places to live would increase in value.

A modelling study conducted in the US focussed on the effects of increased homeworking and reduced commuting on city centre congestion [57]. The results suggest that workers who continue to work on-site would benefit from a shorter commute time due to reduced congestion. Reductions in commuting can ease traffic congestion and pollution in city centres and along commuter corridors, making it a potentially more sustainable way of working. However, increased homeworking is not without other environmental costs. Research by WSP suggests the environmental benefits of homeworking are only evident in summer, as heating both homes and offices during winter increases carbon emissions; to maximise benefits to the environment the authors recommend workers home-work during the summer and office work in the winter [58].

\section{Conclusions}

The COVID-19 pandemic triggered a global recession that has both increased unemployment and widened the disability employment gap in the UK, a trend that has also been 
observed in the USA [16] and is likely to be mirrored in many other countries. Disabled workers are likely to continue to experience higher rates of unemployment, for a longer period, than non-disabled workers, for several reasons. Recessions increase competitiveness for jobs and can encourage more selective recruitment; in the current context there is a risk that employers will be deterred from recruiting disabled workers and workers with long-term health conditions who need to shield during further waves of COVID-19 [59]. In addition, disabled workers are over-represented in employment sectors that were hit hardest by the pandemic and the ensuing recession, and they are less likely to be employed in professional and other non-manual jobs that are conducive to home-working. Consequently, the degree to which disabled workers will be winners or losers in the UK's post-COVID-19 labour market is likely to depend upon the sector and type of work they are employed in.

The fortunes of disabled workers who are employed in desk-based roles look more favourable, however. Many organisations, some of whom had previously withheld homeworking from employees, had to act swiftly and flexibly at the onset of the pandemic to facilitate home-working. This led to a sudden growth in home-working, which a large proportion of employees and employers are reluctant to relinquish. The pandemic challenged organisational policy and practice to be adaptive to sudden societal change; if this leads to a permanent cultural shift to widespread availability of home-working, it has the potential to address not only some of the employment inequities experienced by disabled workers, but also to level the playing field for individuals living in 'left behind' communities with high unemployment who would benefit from greater access to wider labour markets.

Home-working can circumvent some of the barriers that can lead to job loss or underemployment of disabled workers by offering a more inclusive way of working, reducing the need to commute and providing jobseekers with access to a wider labour market. Increased and universal access to home-working for all workers would avoid workplace conflict and stigma that can result from it being requested as a reasonable adjustment [42], and could encourage the recruitment of disabled workers who need to shield into jobs amenable to home-working. It is important, however, that workers have choice and control over the decision to home-work, and that organisations implement measures to mitigate the potentially negative impacts of home-working.

In order for post-pandemic economic growth to be sustainable and equitable, preexisting inequalities within the economy must be addressed $[60,61]$. This requires multisectoral actions and policies that tackle factors contributing to the disability employment gap. For example, the UK still has much to do to increase the provision of inclusive education for disabled children and young people, and to support their transition into the labour market. Disabled people are significantly more likely to have no qualifications, and significantly less likely to have a university degree, compared with non-disabled people [62], and this educational disadvantage reduces their access to professional and higher-paid jobs. More also needs to be done to increase employers' awareness of their legal obligations to provide reasonable adjustments under the Equality Act, and to make clear the business case for providing inclusive workplaces. Rather than returning to 'normal' ways of working, societies have the opportunity to 'build back better', addressing injustices and levelling the playing field for disabled workers in the post-pandemic labour market.

Funding: This research received no external funding.

Conflicts of Interest: The author declares no conflict of interest.

\section{References}

1. World Health Organization Health Emergency Dashboard. Available online: https:/ / covid19.who.int/ (accessed on 27 May 2021).

2. Public Health England. Disparities in the Risks and Outcomes of COVID-19. 2020. Available online: https://assets.publishing. service.gov.uk/government/uploads/system/uploads/attachment_data/file/892085/disparities_review.pdf (accessed on 27 May 2021). 
3. Office for National Statistics. Updated Estimates of Coronavirus (COVID-19) Related Deaths by Disability Status, England: 24 January to 20 November 2020. 2021. Available online: https://www.ons.gov.uk/peoplepopulationandcommunity/birthsdeaths andmarriages/deaths/articles/coronaviruscovid19relateddeathsbydisabilitystatusenglandandwales/24januaryto20novembe r2020\#overview-of-covid-19-related-deaths-by-disability-status (accessed on 27 May 2021).

4. Holland, P.; Burström, B.; Whitehead, M.; Diderichsen, F.; Dahl, E.; Ng, E.; Barr, B.; Nylén, L.; Chen, W.; Thielen, K.; et al. How do macro-level contexts and policies affect the employment chances of chronically ill and disabled people? Paper I: The impact of recession and de-industrialisation. Int. J. Health Serv. 2011, 41, 395-413. [CrossRef] [PubMed]

5. Office for National Statistics. Disability Pay Gaps in the UK: 2018. 2019. Available online: https://www.ons.gov.uk/peoplepopul ationandcommunity/healthandsocialcare/disability/articles/disabilitypaygapsintheuk/2018 (accessed on 27 May 2021).

6. The Work Foundation. Standing Together? COVID-19 and Worker Insecurity in 2020 and Beyond. 2020. Available online: https:/ / www.lancaster.ac.uk/media/lancaster-university/content-assets/documents/lums/work-foundation/Insecurit yBriefing-June20final.pdf (accessed on 27 May 2021).

7. Office for National Statistics. Disability and Employment, UK: 2019. 2019. Available online: https://www.ons.gov.uk/peoplepop ulationandcommunity/healthandsocialcare/disability/bulletins/disabilityandemploymentuk/2019\#main-points (accessed on 27 May 2021).

8. House of Commons Library. Briefing Paper Number 7540, 13 August 2020. Disabled People in Employment. Available online: https:/ / researchbriefings.files.parliament.uk/documents/CBP-7540/CBP-7540.pdf (accessed on 27 May 2021).

9. Baumberg Geiger, B.; van der Wel, K.A.; Tøge, A. Success and failure in narrowing the disability employment gap: Comparing levels and trends across Europe 2002-2014. BMC Public Health 2017, 17, 928.

10. Waddell, G.; Kim Burton, A. Is Work Good for Your Health and Well-Being? An Independent Review. 2006. Available online: https:/ / www.gov.uk/government/publications/is-work-good-for-your-health-and-well-being (accessed on 27 May 2021).

11. Strandh, M.; Winefield, A.; Nilsson, K.; Hammarström, A. Unemployment and mental health scarring during the life course. Eur. J. Public Health 2014, 24, 440-445. [CrossRef]

12. McKee-Ryan, F.; Song, Z.; Wanberg, C.R.; Kinicki, A.J. Psychological and Physical Well-Being During Unemployment: A Meta-Analytic Study. J. Appl. Psychol. 2005, 90, 53-76. [CrossRef] [PubMed]

13. Office for National Statistics. GDP Monthly Estimate, UK: September 2020. Available online: https://www.ons.gov.uk/economy /grossdomesticproductgdp/bulletins/gdpmonthlyestimateuk/september2020 (accessed on 27 May 2021).

14. Bank of England. Agents' Summary of Business Conditions-2020 Q2. 2020. Available online: https:/ / www.bankofengland.co.u k/agents-summary/2020/2020-q2 (accessed on 27 May 2021).

15. Office for National Statistics. A08: Labour Market Status of Disabled People. 2021. Available online: https://www.ons.gov.uk/e mploymentandlabourmarket/peopleinwork/employmentandemployeetypes/datasets/labourmarketstatusofdisabledpeople a08 (accessed on 27 May 2021).

16. Schur, L.A.; Ameri, M.; Kruse, D. Telework after COVID: A "silver lining" for workers with disabilities? J. Occup. Rehabil. 2020 30, 521-536. [CrossRef]

17. Holland, P.; Nylén, L.; Thielen, K.; van der Wel, L.A.; Chen, W.; Barr, B.; Burström, B.; Diderichsen, F.; Andersen, P.K.; Dahl, E.; et al. How do macro-level contexts and policies affect the employment chances of chronically ill and disabled people? Part II: The impact of active and passive labour market policies. Int. J. Health Serv. 2011, 41, 415-430. [CrossRef] [PubMed]

18. Avdiu, B.; Nayyar, G. When face-to-face interactions become an occupational hazard: Jobs in the time of COVID-19. Econ. Lett. 2020, 197, 109648. [CrossRef]

19. Office for National Statistics. Outcomes for Disabled People in the UK: 2020. 2021. Available online: https://www.ons.gov.uk/p eoplepopulationandcommunity/healthandsocialcare/disability/articles/outcomesfordisabledpeopleintheuk/2020 (accessed on 27 May 2021).

20. Norström, F.; Virtanen, P.; Hammarström, A.; Gustafsson, P.E.; Janlert, U. How does unemployment affect self-assessed health? A systematic review focusing on subgroup effects. BMC Public Health 2014, 14, 1310. [CrossRef] [PubMed]

21. Maroto, M.L.; Pettinicchio, D.; Lukk, M. Working Differently or Not at All: COVID-19's Effects on Employment among People with Disabilities and Chronic Health Conditions. Sociol. Perspect. 2021. [CrossRef]

22. Collins, C.; Ocampo, O.; Paslaski, S. Billionaire Bonanza 2020: Wealth Windfalls, Tumbling Taxes, And Pandemic Profiteers. Institute for Policy Studies, 2020. Available online: https://ips-dc.org/billionaire-bonanza-2020/ (accessed on 27 May 2021).

23. Furceri, D.; Loungani, P.; Ostry, J.D.; Pizzuto, P. Will Covid-19 affect inequality? Evidence from past pandemics. Covid Econ. 2020, 12, 138-157.

24. Scope. Disabled People Fear Being 'Pushed Out' of Post-Lockdown World as Shielding Pauses. 2020. Available online: https: / / www.scope.org.uk/media/press-releases/disabled-people-pushed-out-lockdown/ (accessed on 27 May 2021).

25. O'Connor, D.B.; Aggleton, J.P.; Chakrabarti, B.; Cooper, C.L.; Creswell, C.; Dunsmuir, S.; Fiske, S.T.; Gathercole, S.; Gough, B.; Ireland, J.L.; et al. Research priorities for the COVID-19 pandemic and beyond: A call to action for psychological science. $\mathrm{Br}$. J. Psychol. 2020, 111, 603-629. [CrossRef]

26. Foster, D.; Hirst, N. Legally Disabled? The Impact of COVID-19 on the Employment and Training of Disabled Lawyers in England and Wales: Opportunities for Job Re-Design and Best Practice. Cardiff University, 2020. Available online: http: //legallydisabled.com/wp-content/uploads/2020/11/Covid-report-TLS-Oct-2020-FINAL.pdf (accessed on 27 May 2021). 
27. Legislation.gov.uk. 2010. Equality Act 2010. Available online: http://www.legislation.gov.uk/ukpga/2010/15/contents (accessed on 27 May 2021).

28. Holland, P.; Clayton, S. Navigating employment retention with a chronic health condition: A meta-ethnography of the employment experiences of people with musculoskeletal disorders in the UK. Disabil. Rehabil. 2020, 42, 1071-1086. [CrossRef]

29. Pinder, R. Bringing back the body without the blame? The experience of ill and disabled people at work. Sociol. Health Illn. 1995, 17, 605-631. [CrossRef]

30. Holland, P.; Collins, A.M. "Whenever I can I push myself to go to work": A qualitative study of experiences of sickness presenteeism among workers with rheumatoid arthritis. Disabil. Rehabil. 2018, 40, 404-413. [CrossRef] [PubMed]

31. Holland, P.; Collins, A.M. Supporting and retaining employees with rheumatoid arthritis: The importance of workplace social support. Int. J. Hum. Resour. Manag. 2020. [CrossRef]

32. Gewurtz, R.; Kirsh, B. Disruption, disbelief and resistance: A meta-synthesis of disability in the workplace. Work 2009, 34, 33-44. [CrossRef]

33. Lupton, P.; Haynes, B. Teleworking-The perception-reality gap. Facilities 2000, 18, 323-327. [CrossRef]

34. Felstead, A.; Henseke, G. Assessing the growth of remote working and its consequences for effort, well-being and work-life balance. New Technol. Work. Employ. 2017, 32, 195-212. [CrossRef]

35. Office for National Statistics. Coronavirus and Homeworking in the UK Labour Market: 2019. 2020. Available online: https://www.ons.gov.uk/employmentandlabourmarket/peopleinwork/employmentandemployeetypes/articles/coronaviru sandhomeworkingintheuklabourmarket/2019 (accessed on 27 May 2021).

36. Felstead, A.; Reuschke, D. 'Homeworking in the UK: Before and during the 2020 Lockdown', WISERD Report, Cardiff: Wales Institute of Social and Economic Research. 2020. Available online: https://wiserd.ac.uk/publications/homeworking-uk-and-d uring-2020-lockdown (accessed on 27 May 2021).

37. Chung, H.; Seo, H.; Forbes, S.; Birkett, H. Working from Home during the COVID-19 Lockdown: Changing Preferences and the Future of Work. University of Birmingham and University of Kent. 2020. Available online: http://wafproject.org/covidwfh (accessed on 27 May 2021).

38. Ipsen, C.; Kirchner, K.; Hansen, J.P. Experiences of Working from Home in Times of Covid-19 International Survey Conducted the First Months of the National Lockdowns March-May. 2020. Available online: https://orbit.dtu.dk/en/publications/experiences -of-working-from-home-in-times-of-covid-19-internation (accessed on 27 May 2021).

39. West, W.D.; Anderson, A. Telework and employees with disabilities: Accommodation and funding options. J. Vocat. Rehabil. 2005, $23,115-122$.

40. Kaplan, S.; Weiss, S.; Moon, N.W.; Baker, P. A Framework for Providing Telecommuting as a Reasonable Accommodation: Some Considerations on a Comparative Case Study. Work 2006, 27, 431-440.

41. McNaughton, D.; Rackensperger, T.; Dorn, D.; Wilson, N. 'Home Is at Work and Work Is at Home': Telework and Individuals Who Use Augmentative and Alternative Communication. Work 2014, 48, 117-126. [CrossRef]

42. Linden, M.; Milchus, K. Teleworkers with disabilities: Characteristics and accommodation use. Work 2014, 47, 473-483. [CrossRef] [PubMed]

43. The Remote Work Report by GitLab: The Future of Work is Remote. March 2020. Available online: https://page.gitlab.com/rs/1 94-VVC-221/images/the-remote-work-report-by-gitlab.pdf (accessed on 27 May 2021).

44. Foster, D.; Hirst, N. Legally Disabled? The Career Experiences of Disabled People Working in the Legal Profession. Cardiff University, 2020. Available online: http:/ /legallydisabled.com/researchreports/ (accessed on 27 May 2021).

45. Bloom, N.; Liang, J.; Roberts, J.; Ying, Z.J. Does Working from Home Work? Evidence from a Chinese Experiment. Q. J. Econ. 2015, 130, 165-218. [CrossRef]

46. Forbes, S.; Birkett, H.; Evans, L.; Chung, H.; Whiteman, J. Managing Employees during the COVID-19 Pandemic: Flexible Working and the Future of Work; University of Kent: Canterbury, UK; University of Birmingham: Birmingham, UK, 2021.

47. Parry, J.; Young, Z.; Bevan, S.; Veliziotis, M.; Baruch, Y.; Beigi, M.; Bajorek, Z.; Salter, E.; Tochia, C. Working from Home under COVID-19 Lockdown: Transitions and Tensions, Work after Lockdown. 2021. Available online: https:/ / www.employment-studi es.co.uk/resource/working-home-under-covid-19-lockdown (accessed on 27 May 2021).

48. Institute of Directors. Homeworking Here to Stay. 2020. Available online: https://www.iod.com/news/news/articles/Homeworking-here-to-stay-new-IoD-figures-suggest (accessed on 27 May 2021).

49. Department for Work and Pensions. New Help on Offer for Disabled People Working from Home during the Pandemic. 2020. Available online: https://www.gov.uk/government/news/new-help-on-offer-for-disabled-people-working-from-home-duri ng-the-pandemic (accessed on 27 May 2021).

50. Emerson, E.; Fortune, N.; Llewellyn, G.; Stancliffe, R. Loneliness, social support, social isolation and wellbeing among working age adults with and without disability: Cross-sectional study. Disabil. Health J. 2021, 14. [CrossRef] [PubMed]

51. University of Cambridge. "Pay the Wi-Fi or Feed the Children": Coronavirus has Intensified the UK's Digital Divide. 2020. Available online: https:/ / www.cam.ac.uk/stories / digitaldivide (accessed on 27 May 2021).

52. Office for National Statistics. Exploring the UK's Digital Divide. 2019. Available online: https://www.ons.gov.uk/peoplepopulat ionandcommunity /householdcharacteristics/homeinternetandsocialmediausage/articles/exploringtheuksdigitaldivide/201 9-03-04\#what-is-the-pattern-of-internet-usage-among-disabled-people (accessed on 27 May 2021). 
53. Bambra, C.; Munford, L.; Alexandros, A.; Barr, B.; Brown, H.; Davies, H.; Konstantinos, D.; Mason, K.; Pickett, K.; Taylor, C.; et al. COVID-19 and the Northern Powerhouse: Tackling Inequalities for UK Health and Productivity; Northern Health Sciences Alliance: Newcastle, UK, 2020.

54. Bambra, C.L.; Munford, L.; Brown, H.; Wilding, A.; Robinson, T.; Holland, P.; Barr, B.; Hill, H.; Regan, M.; Rice, N.; et al. Health for Wealth: Building a Healthier Northern Powerhouse for UK Productivity; Northern Health Sciences Alliance: Newcastle, UK, 2018.

55. Ussher, K.; Rotik, M.; Jeyabraba, M. Post Pandemic Places. DEMOS. 2021. Available online: https://demos.co.uk/wp-content/u ploads / 2021/03/Post-Pandemic-Places-Report.pdf (accessed on 27 May 2021).

56. De Fraja, G.; Matheson, J.; Rockey, J.C. Zoomshock: The Geography and Local Labour Market Consequences of Working from Home. Covid Econ. 2021, 64, 1-41.

57. Delventhal, M.; Kwon, E.; Parkhomenko, A. How Do Cities Change When We Work from Home? 2020. Available online: http:/ / dx.doi.org/10.2139/ssrn.3746549 (accessed on 27 May 2021).

58. WSP. Office vs Home Working: How We Can Save Our Carbon Footprint. 2020. Available online: https://www.wsp.com/en-G B/insights / office-vs-home-working-how-we-can-save-our-carbon-footprint (accessed on 27 May 2021).

59. Leonard Cheshire. Locked Out of the Labour Market: The Impact of Covid-19 on Disabled Adults in Accessing Good Work-Now and into the Future. 2020. Available online: https:/ / www.leonardcheshire.org/sites/default/files/2020-10/Locked-out-of-lab our-market.pdf (accessed on 27 May 2021).

60. United Nations. Trade and Development Report, 2020. From Global Pandemic to Prosperity for All: Avoiding Another Lost Decade. 2020. Available online: https:/ / unctad.org/en/PublicationsLibrary/tdr2020_en.pdf (accessed on 27 May 2021).

61. Vox EU. How the UK Government Should Respond to the Unequal Local Economic Impacts of COVID-19. 2020. Available online: https:/ / voxeu.org/article/how-uk-government-should-respond-unequal-local-economic-impacts-covid-19 (accessed on 27 May 2021).

62. Office for National Statistics. Disability and Education, UK. 2019. Available online: https://www.ons.gov.uk/peoplepopulationa ndcommunity/healthandsocialcare/disability/bulletins/disabilityandeducationuk/2019 (accessed on 27 May 2021). 